\title{
1 Coated Stainless Steel Bipolar Plates for Proton Exchange Membrane Electrolyzers
}

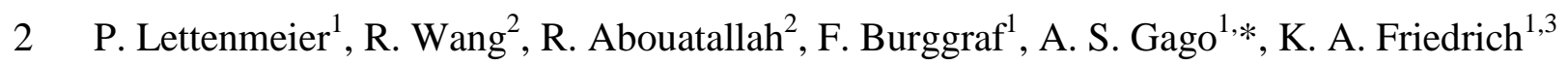

$3{ }^{1}$ Institute of Engineering Thermodynamics, German Aerospace Center, Pfaffenwaldring 38-40,

$4 \quad$ Stuttgart, 70569, Germany

$5{ }^{2}$ Hydrogenics Corporation, 220 Admiral Boulevard, Mississauga, ON L5T 2N6, Canada

$6{ }^{3}$ Institute of Energy Storage, University of Stuttgart, Stuttgart, 70550, Germany

*Corresponding author: Tel.: +49 711 6862-8090, fax: +49 711 6862-747, e-mail address: aldo.gago@dlr.de (A. S. Gago). 


\section{$7 \quad$ Keywords}

8 Bipolar plates; Coatings; Titanium; Stainless steel; PEM electrolysis; PEM electrolyzer 


\section{Abstract}

12 Given its rapid response to fluctuating currents and wide operation range, proton exchange

13 membrane (PEM) water electrolysis is utmost suitable for generation of hydrogen from

14 renewable power. However, it is still hindered by the high cost of the stack components

15 compared to those used in the alkaline technology. In particular, the titanium bipolar plates

16 (BPP) are an issue and the replacement of this metal by stainless steel is a challenge, due to the

17 highly corrosive environment inside PEM electrolyzer stack. Herein, we coat stainless steel BPPs

18 with $50-60 \mu \mathrm{m} \mathrm{Ti}$ and $1.5 \mu \mathrm{m}$ Pt coatings by vacuum plasma spraying (VPS) and magnetron

19 sputtering physical vapor deposition (PVD), respectively. The BPPs are evaluated at constant 1

$20 \mathrm{~A} \mathrm{~cm}^{-2}$ for more than $1000 \mathrm{~h}$. The thermally sprayed Ti coatings fully protect the stainless steel

21 substrate during this period of time, and the Pt surface modification allows achieving a cell

22 performance comparable to the baseline. 
25 In 1800, William Nicholson and Anthony Carlisle discovered the electrolysis of water into $\mathrm{H}_{2}$ 26 and $\mathrm{O}_{2}$, by applying direct current (DC) and for a long time was the main technique for hydrogen

27 production for industry. ${ }^{1}$ Over 200 years later, the splitting of water is experiencing a renaissance

28 due to energy applications and proton exchange membrane (PEM) electrolysis is the most

29 dynamic technique, which was reported in 1973 by Russell and coworkers. ${ }^{2}$ In this context,

30 hydrogen is nowadays expected to act as a carbon neutral energy vector to introduce renewable

31 electricity into other sectors. ${ }^{3}$ Compared to the well-established alkaline technology, PEM

32 electrolyzers have several advantages such as high efficiency, rapid response, compact system

33 design, and extended dynamic operation range. ${ }^{4-9}$ Moreover, gas purities up to $99.995 \%$ can be

34 achieved with the PEM technology while only $99.5 \%$ for alkaline electrolyzers. ${ }^{10}$ Conversely, for

35 small production rate, PEM technology is more expensive than alkaline. ${ }^{11,12}$ However, it

36 becomes more competitive and likely cheaper in large production rates, especially in the

37 Megawatt input power range.

38 The stack, which is assembled with several cells connected in series, is the key part of the PEM

39 electrolyzer unit. ${ }^{6}$ The membrane electrode assembly (MEA) is one core component of a PEM

40 cell. Current collectors (CC) on both sides of the MEA, which are permeable for water and the

41 product gases, allow current to flow to and from the electrodes. ${ }^{13-15}$ The two half-cells are

42 surrounded by so called bipolar plates (BPP) or separators, which usually have flow fields that

43 allow the reactant water to be transported to the $\mathrm{CC}$ and the product gases to be removed 44 efficiently. ${ }^{16,17}$ 
45 The stack comprises about $60 \%$ of the total cost of the PEM electrolyzer and the titanium bipolar

46 plates (BPP) are responsible for half the cost of the stack. ${ }^{8}$ The BPPs are manufactured from

47 titanium, which is highly stable to corrosion in oxidative environments, but machining this metal

48 is complicated and expensive. ${ }^{18,19}$ Furthermore, semi-conductive oxides form on its surface as a

49 result of anodization, and this passive layer affects negatively the performance and durability of

50 the electrolyzer. ${ }^{20-23}$ Thereby, the reduction or total replacement of massive Ti in PEM

51 electrolyzers by low cost materials is a pressing issue for the industry.

52 The use of stainless steel as base material for manufacturing BPPs of proton exchange membrane

53 fuel cell (PEMFC) has been extensively reported. When used in fuel cells, it requires a high

54 corrosion resistance coating with excellent electronic properties. ${ }^{24-26}$ In this context, conductive

55 coatings such as $\mathrm{C},{ }^{27-29} \mathrm{Au},{ }^{30} \mathrm{TiN},{ }^{31} \mathrm{TiN} / \mathrm{C},{ }^{32} \mathrm{TaN},{ }^{33} \mathrm{CrN},{ }^{34}$ and $\mathrm{SnO}_{2}: \mathrm{F}^{35}$ have been extensively

56 evaluated for corrosion protection of PEMFC stainless steel bipolar plates. Nevertheless, these

57 coated-BPPs are not currently used in PEM electrolyzers. The reason is that the high cell voltage,

58 at which the electrolyzer operates in nominal conditions $\left(2 \mathrm{~V}, 40-60{ }^{\circ} \mathrm{C}, 1 \times 10^{5} \mathrm{~Pa}\right.$ or higher $)$,

59 accelerates corrosion, which might not be avoided with PEMFC coatings.

60 An approach for developing protective coatings for BPPs of PEM electrolyzers can be: (i)

61 Deposition of a thick Ti coating by thermal spraying ${ }^{36-40}$ for corrosion protection of stainless

62 steel; (ii) Surface modification of the Ti coating to decrease contact resistance. ${ }^{21,41,42}$ We have

63 recently shown that a coating of $\mathrm{Ti}$ with a subsequent surface modification with $\mathrm{Pt}(\mathrm{Pt} / \mathrm{Ti})$

64 protects stainless steel from corrosion over an extended period of time, while maintaining its

65 electrical properties. ${ }^{39}$ In our work the corrosion evaluation was performed in a simulated

66 environment of PEM electrolyzer for short periods. However, long-term testing of the coatings in

67 a commercial PEM electrolyzer is crucial to demonstrate their capability for industrial 
68 applications. In this work, we report the results of a $1000 \mathrm{~h}$ test on a stack with $\mathrm{Ti}$ and $\mathrm{Pt} / \mathrm{Ti}$

69 coated stainless steel bipolar plates in a commercial PEM electrolyzer. Neither decrease in the

70 electrolyzer performance nor degradation of the stainless steel substrate was observed, proving

71 that this metal can be used as base material for manufacturing low cost bipolar plates.

\section{2. Experimental}

\subsection{Coating process and stack assembly}

74 The development of the $\mathrm{Ti}$ and $\mathrm{Pt}$ coatings on stainless steel was reported elsewhere. ${ }^{39}$ The 75 coatings were deposited on $120 \mathrm{~cm}^{2}$ active area $316 \mathrm{~L}$ stainless steel round BPP from 76 Hydrogenics. The plates were previously sand-blasted with $\mathrm{SiO}_{2}$ powder to increase the surface

77 roughness of the support thus the adherence of the Ti coating to it is improved. A feedstock of

78 titanium powder (grade 1, grain size $<45 \mathrm{~mm}$, TLS Technik Spezialpulver) was used. The 79 coating was applied on both sides of the plates. The chamber pressure was 50 mbar. A plasma

80 enthalpy of $21.3 \mathrm{MJ} \mathrm{kg}^{-1}$ was achieved by carefully controlling the flow rates of $\mathrm{H}_{2}, \mathrm{He}$ and Ar,

81 The presence of $\mathrm{H}_{2}$ decreases the partial pressure of $\mathrm{O}_{2}$ and its reduction by $\mathrm{H}_{2}$ takes place, thus

82 preventing the oxidation of $\mathrm{Ti}$ into $\mathrm{TiO}_{2}$. The former increases the electrical resistance of the $\mathrm{Ti}$

83 coating. Thereafter, a step of capillary sealing procedure allowed to fully densify the Ti coatings.

84 Finally, the area of the flow field that is in contact with the current collectors was sanded with

85 SC4000 paper and rinsed with deionized (DI) water. No abrasives were used. An additional layer

86 of $\mathrm{Pt}$ was deposited on some of the Ti-coated stainless steel BPP, by magnetron sputtering

87 physical vapor deposition (PVD). The BPP were assembled in a rainbow stack and in which all

88 cells had the same commercial membrane electrode assemblies MEAs (Greenerity E300,

89 N115CS membrane), metallic current collectors and carbon-based gas diffusion layers (GDL). 
90 Table 1 enlists the configuration of the cell coatings in the stack. The first two cells, which had

91 Ti bipolar plates with proprietary coatings from Hydrogenics, were used as a baseline for 92 comparison purposes.

\section{2.2. PEM electrolyzer and impedance tests}

94 The stack (model 92E, Hydrogenics), Figure 1a, with coated stainless steel bipolar plates was

95 tested in a commercial PEM electrolyzer (0.75-2.5 $\mathrm{Nm}^{3} \mathrm{H}_{2} \mathrm{~h}^{-1}$ Hylyzer Hydrogen Generator,

96 Hydrogenics), Figure 1b. The electrolyzer was running for several days as part of an activation

97 protocol until it reached a stable voltage at a given current density. Then the stack was evaluated

98 at constant $1 \mathrm{~A} \mathrm{~cm}^{-2}$, for $1000 \mathrm{~h}$, at $38{ }^{\circ} \mathrm{C}$, and $6.5 \times 10^{5} \mathrm{~Pa}$ balanced pressure system. This

99 current density was deliberately chosen to compare degradation rates with other reports, in which

100 PEM electrolyzers with Ti BPP were operated at least 100 h. $^{18,43-46}$ Polarization curves were

101 recorded before, and after 500 and $1000 \mathrm{~h}$, from 0.01 to $1 \mathrm{~A} \mathrm{~cm}^{-2}$ (rectifier step rate: $4.2 \mathrm{~mA} \mathrm{~cm}{ }^{-2}$

$102 \mathrm{~s}^{-1}$ ) at $29{ }^{\circ} \mathrm{C}$ and $6.5 \times 10^{5} \mathrm{~Pa}$ balanced pressure system. Temperature fluctuations were

103 negligible in this current density range. Likewise, electrochemical impedance spectroscopy (EIS)

104 measurements were carried out with a potentiostat/galvanostat (Zahner elektrik IM6) coupled

105 with a booster (Module PP240) for each cell at $27{ }^{\circ} \mathrm{C}$. Measurements were carried out at 20 A

106 with an amplitude of $3 \mathrm{~A}$ and frequencies between 0.1 and $750 \mathrm{~Hz}$. The results were fitted to an

107 equivalent electrical circuit consisting of an ohmic resistance $\left(\mathrm{R}_{1}\right)$ connected in series with two

108 sections of resistance - constant phase element $\left(\mathrm{R}_{2}-\mathrm{CPE}, \mathrm{R}_{3}-\mathrm{CPE}\right)$. The first element, $\mathrm{R}_{1}$,

109 represents the ohmic behaving components of the cell, containing electrical and ionic resistances.

110 The second component, $\mathrm{R}_{2}$-CPE, represents capacitive double layer effects in the electrode of 111 ionic and electric components, and the third component, $\mathrm{R}_{3}-\mathrm{CPE}$, correspond to the charge 112 transfer resistance of the oxygen evolution reaction. 
113 The inlet water resistance of the stack was kept higher than $10 \mathrm{M} \Omega \mathrm{cm}^{-1}$ at all time, by means of

114 a DI water resin system, which traps transition metal ions as well as $\mathrm{S}, \mathrm{F}$ and $\mathrm{Si}$. Therefore, the

115 resin can be used to determine qualitatively stack degradation products from catalysts and

116 coatings. X-ray photon electron spectroscopy (XPS) was performed at the end of the $1000 \mathrm{~h}$ test

117 looking for Fe or other elements of the 316L.

118 2.3. Contact resistance measurements

119 Interfacial contact resistance (ICR) vs. compaction force measurements were performed after the

$1201000 \mathrm{~h}$ test to evaluate degradation effects due to formation of semiconducting oxide layers on

121 the surface of the coatings. This technique is widely used to determine ICR of BBP for

122 PEMFC. ${ }^{32,35,47-49}$ We assume that the ICR parameter of the coated stainless steel BPP before the

123 test is similar to the one determined on $\mathrm{Ti}$ and $\mathrm{Pt} / \mathrm{Ti}$ coated dummy flat samples, ${ }^{39}$ since the

124 coating parameters in this work were the same. The bipolar plates were placed between two

125 pieces of GDL carbon paper (280 $\mu \mathrm{m}$ thick) and two copper cylinders, which were previously

126 cleaned with $0.5 \mathrm{M} \mathrm{H}_{2} \mathrm{SO}_{4}$. The ICR measurements were performed by applying a current of $5 \mathrm{~A}$

127 and the contact pressure was varied from 20 to $200 \mathrm{~N} \mathrm{~cm}^{-2}$. The separation between the channel

128 ribs and width of the rib is in both cases $\sim 1 \mathrm{~mm}$ after coating. Therefore, the compaction force

129 was adjusted by a factor of two. The voltage was measured with the same potentiostat used for

130 the EIS measurements. An electrical circuit, which represents each interface by a resistor, ${ }^{49}$ was

131 used to determine the ICR of each plate.

132 2.4. Scanning electron microscopy (SEM)

133 Analysis of the cross section of the coated-BPPs was carried with an ULTRA plus (Zeiss Corp.)

134 scanning electron microscope. The images were recorded with the secondary electrons an 
135 integrated AsB GEMINI lens detector, separating the back scattered electron (BSE) signal. The

136 acceleration voltage was $15 \mathrm{kV}(1 \mathrm{~nm}$ resolution) and the working distance $8.1 \mathrm{~mm}$.

\section{3. Discussion of results}

\subsection{Coated stainless steel BPP}

139 One concern of every coating procedure is how well the layer can cover zones in the BPPs that 140 are more prone to corrosion than others. Cross-section SEM images of the Ti-coated stainless

141 steel BPPs, readily after being coated are presented in Figure 1c and 1d. The micrographs reveal 142 that the coating covers all the regions of the manifolds, the exposed 3D areas of the flow 143 field, inlet/outlet holes, edges, corners and even some regions of the backside of the BPP. It is 144 worthwhile noting that it was not necessary to tilt the plate to obtain a uniform thickness of the 145 coating on all the surface of the ribs of the BPP. The BPP with Pt/Ti coatings were not analyzed 146 by SEM prior the assembly of the stack, assuming that the morphology of the coatings is similar 147 coatings reported elsewhere. ${ }^{39}$

148 3.2. Cell performance

149 The 92E stack with the coated-BPPs was mounted in the Hylyzer PEM electrolyzer and operated 150 for a few days as part of an activation process. Thereafter, current-voltage curves from 0.01 to 1 $151 \mathrm{~A} \mathrm{~cm}^{-2}$ were recorded for each cell at a rectifier step rate of $4.2 \mathrm{~mA} \mathrm{~cm}^{-2} \mathrm{~s}^{-1}$, maintaining a stack 152 temperature of $29^{\circ} \mathrm{C}$, Figure $2 \mathrm{a}$. According to the cell configurations presented in Table 1 , the 153 cells with Ti-coated cathodes without $\mathrm{Pt}$, cell 4 and 5, showed the highest $E_{\text {cell }}$ at $1 \mathrm{~A} \mathrm{~cm}^{-2}$. The

154 Nyquist plots of the EIS measurements at $27^{\circ} \mathrm{C}$ and $0.166 \mathrm{~A} \mathrm{~cm}^{-2}$ are presented in Figure $2 \mathrm{~b}$. It 155 needs to be mentioned, the the $\mathrm{E}_{\text {cell }}$ of the baseline and the Pt/Ti coated cells at $38{ }^{\circ} \mathrm{C}$ is high 
compared to what it has been reported with same stack technology. ${ }^{50}$ The issue can originate

157 form an increase of water pressure in the flow field channels and sealing compression in the 158 grooves caused by the thick Ti coating, which affected the performance of the whole stack.

159 Consequently, the width of the flow field channels and sealing grooves should be adjusted if they

160 are to be coated with 50-60 $\mu \mathrm{m}$ Ti. As a result, our study can only compare the performance of

161 the Pt/Ti coated cells with the baseline in the same stack. Further work will address this issue.

162 First, the EIS results show that cell 4 and 5 have much higher ohmic resistance $\left(\mathrm{R}_{1}\right)$ compared to

163 the others. As it will be shown in the next section, the ICR of the Ti coating with the carbon-

164 based GDL is much higher than the ICR of the Pt coating with the same GDL. One can conclude

165 that the passivation of Ti is detrimental for the cell performance when using a carbon based GDL

166 in the cathode. Indeed, a significant improvement in the performance of unitized reversible fuel

167 cells (URFC) has been previously reported, when the Ti bipolar plates are coated with $\mathrm{Pt}^{21}$ or

168 Au. ${ }^{42}$ Second, the kinetic or activation resistance $\left(R_{2}\right)$ is similar in all cells, since they all have

169 MEAs with similar catalysts. None of the cells presented mass transport issues, which accounts

170 for an excellent gas bubble management in the catalyst layers, ${ }^{51}$ thin current collectors with high

171 porosity ${ }^{13,52,53}$ and optimized flow field of the bipolar plate. ${ }^{16}$ Lastly, cell 6, having Pt/Ti coating

172 on anode and cathode side of the stainless stell BPP, showed the lowest $E_{\text {cell }}$ at $1 \mathrm{~A} \mathrm{~cm}^{2}$.

$173 \mathrm{~A} 1000 \mathrm{~h}$ test at $1 \mathrm{~A} \mathrm{~cm}^{-2}$ was carried out readily after the initial electrochemical characterization

174 of the stack. The resulting $E_{\text {cell }} v s$. time characteristics of cell $1-6$ are presented in Figure 3 . The

175 electrolyzer was shut down after $\sim 500 \mathrm{~h}$ of operation and it was kept in this mode for almost 100

$176 \mathrm{~h}$ to determine degradation effects when the electrolyzer is turned off. These conditions will

177 necessarily occur in any application when $\mathrm{H}_{2}$ is not constantly required. Current potential curves

178 and EIS were recorded at the end of the stand-by period, Figure 4a and 4b, respectively. Once the 
179 electrolyzer was brought back in operation, the voltage of cell 4 and 5 was more than $100 \mathrm{mV}$

180 higher than before the shutting down, while for the other four cells such changes did not occur.

181 By fitting the equivalent circuit proposed in Section 2.2, the changes of the ohmic resistances of

182 each cell can be quantified. The ohmic resistance of the surface modified cells decreases almost

183 homogeneously by an average value of $45 \mathrm{~m} \Omega \mathrm{cm}^{-2}$. Conversely, cell 4 and cell 5 increased their

184 ohmic resistance by 243 and $117 \mathrm{~m} \Omega \mathrm{cm}^{-2}$, respectively. Post-mortem analysis (Section 3.3) will

185 show that not only the anode side of the Ti coated plate oxidized, but also the cathode side

186 experienced degradation. The negative effect might have occurred during the stand-by period as

187 concluded from the time equivalence of degradation and stand-by period, although it was not

188 directly proven.

189 The change of $E_{\text {cell }}$ and $\mathrm{R}_{1}$ for all the cells is summarized in Figure $5 \mathrm{a}$ and $5 \mathrm{~b}$, respectively. In 190 overall, cell 1 (baseline) and cell 6 (Pt/Ti coating on anode and cathode) showed the highest

191 performance and no increase in $E_{\text {cell }}$. The main difference between them is that cell 1 is made of $192 \mathrm{Ti}$, while cell 6 uses stainless steel as based material for its manufacture. Except for cells 4, the 193 performance of the cells improved slightly overtime, which can be explained by a progressive 194 decrease of the ohmic $\left(\mathrm{R}_{1}\right)$, Figure $5 \mathrm{~b}$. Cell 4 and cell 5 improve significantly their performance 195 in the initial $100 \mathrm{~h}$ until reaching a steady state. From Figure 3 one can only observe the 196 improvement of their performance in the initial $100 \mathrm{~h}$, which is a complex activation process 197 (recovering) not yet fully explored in the literature of PEM electrolysis. Both cells progressively 198 continue degrading and in particular after the shut down period, which can be well appreciated 199 from Figure 4a (Increase in $E_{\text {cell }}$ ) and Figure 5a (decrease in $\mathrm{R}_{1}$ ). The performance of both cells 200 did not recover anymore for the subsequent $900 \mathrm{~h}$. From the polarization curves of Figure 2a and 
201 4a (as well as in Figure 5b: high increase in $\mathrm{R}_{1}$ ) one can observe that Cell 4 degraded more than

202 Cell 5 after the $1000 \mathrm{~h}$ test.

203 Moreover, other works have reported a concomitant increase in $E_{\text {cell }}$ has as result of 204 degradation $^{18,43-46}$ and the cause is mostly attributed to poisoning of the MEA with metallic

205 cations such as Fe. ${ }^{54-57}$ This metal is present in the DI water in small amounts and it increases its 206 concentration over time in the $\mathrm{O}_{2}$ separator due to the electrolysis process. Therefore, a DI water 207 resin is necessary for trapping the Fe ions and it needs to be replaced regularly. The effect of Fe 208 poisoning in PEM electrolyzers is not well studied so far but it is expected that Fe will decrease 209 the ionic conductivity and deposit on the cathode. ${ }^{58}$ As a result, the $E_{c e l l}$ will increase over time. 210 In our study, we did neither observe rise of $E_{\text {cell }}$ of the cells with $\mathrm{Pt} / \mathrm{Ti} / \mathrm{ss}$ bipolar plates nor 211 abnormal increase of iron concentration in the DI water resin, and nor pitting corrosion after the $2121000 \mathrm{~h}$ test.

213 From the results discussed in this section, it can be concluded the following: (i) The titanium 214 coating does not need further surface modification on the anode side if it is in contact with a 215 metallic collector; (ii) The titanium coating should be modified, with Pt for example, if carbon 216 paper GDL is to be used as cathode current collector; (iii) The stainless steel BPP might not 217 require a $\mathrm{Ti}$ coating on the cathode side. Further investigations are necessary in order to 218 demonstrate (iii), as corrosion of stainless steel might occur in the periods when the electrolyzer 219 is turned off.

\section{3.3. Degradation and post-mortem analysis}

221 After disassembling of the stack, a noticeable darkness of the surface of the Ti coating in the 222 cathode and anode side of the plate was observed. The grayish surface of the coating on the 
223 anode side reappeared after sanding it for a few minutes with SC4000 paper, thus removing the

224 oxide layer. The ICR vs. compaction force measurements were carried on areas of the BPP

225 before and after sanding procedure to evaluate the effect of degradation. Figure 6 summarizes the

226 results on $\mathrm{Ti} / \mathrm{ss}$ while $\mathrm{Pt} / \mathrm{Ti} / \mathrm{ss}$ is included for comparison. First, one can observe that the $\mathrm{Pt}$

227 surface modification reduces the contact resistance of $\mathrm{Ti}$ with the carbon paper almost 2 orders

228 of magnitude at $120 \mathrm{~N} \mathrm{~cm}^{-2}$ and does not change with the compaction pressure, which was

229 already observed in our previous work. ${ }^{39}$

230 Secondly, the surface of the cathode degraded more than the anode side. If the cause was

231 oxidation of the Ti coating, certainly, it did not take place during operation of the electrolyzer,

232 but most likely during the stand-by period in which the electrolyzer was turned off. One must

233 also consider the possibility of degradation of the cathode Ti coating by $\mathrm{H}_{2}$ embrittlement. $^{59,60}$

234 The results of ICR $v s$. compaction force suggest that the cathode side might not necessarily need

235 to be coated with $\mathrm{Ti}$ as austenitic stainless steels are more resistant to hydrogen

236 enbrittlement. ${ }^{61,62}$ In the case of the Pt/Ti-coated stainless steel BPP, the Pt coating peeled off in

237 some areas of the grooves of the BPP in which the sealing is inserted. However, no signs of

238 degradation of the Pt coating were observed in the contact area with either the metallic CC

239 (anode) or carbon-based GDL (cathode). The peeling of the thermally sprayed Ti coating was

240 neither observed for the Ti/ss nor Pt/Ti/ss BPPs.

241 Samples of the DI water resin were collected at the beginning (fresh) and the end (used) of the

$2421000 \mathrm{~h}$ and they were analyzed by X-ray photon electron microscopy (XPS). Table 2 enlists the

243 elements that were detected, and in particular $\mathrm{Ti}$ and Fe concentration in the resin increased by

2440.3 and $0.1 \mathrm{wt} \%$, respectively, after the $1000 \mathrm{~h}$ test. The former might originate in the

245 degradation of the Ti BBPs (cell 1-2) or the Ti coating (cell 3 - 4). Yet, the element of interest is 
246 iron, which is a product of pitting corrosion of stainless steel. The increase of this metal in the

247 resin is negligible and even higher amounts have been observed for other E92 stacks having only

248 Ti BPPs (measurements not shown). Therefore, the traces of Fe in the resin can only arise from

249 inlet water for the entire system, as corrosion of stainless 316L steel pipes and valves in DI water

250 is unlikely. ${ }^{63}$ Finally, Figure 7a shows a SEM cross-section of optical image of the Ti coating on

251 the stainless steel BPPs after the $1000 \mathrm{~h}$ test. A close up image of the Pt/Ti coating deposited on

252 the anode side of the BPP is presented on in Figure $7 \mathrm{~b}$. Neither peeling off the coatings nor

253 corrosion of the substrate (pinholes) was observed in any plate. The electrochemical and post-

254 mortem physical analysis clearly support the use of stainless steel as base material for BPPs of

255 PEM electrolyzers.

\section{4. Conclusions}

257 Thermally sprayed Ti-coated stainless steel bipolar plates of PEM electrolyzer were tested for

258 more than $1000 \mathrm{~h}$ at constant $1 \mathrm{~A} \mathrm{~cm}^{-2}$. The coating fully protected the stainless steel substrate;

259 however it degraded when used in the cathode and in contact with the carbon-based GDL,

260 resulting in a significant increase of cell voltage $\left(E_{c e l l}\right)$. The oxidation of the Ti coating on the

261 anode side did not pose a negative effect. The problem was solved by modifying the surface of

262 the Ti coating with a $1.5 \mu \mathrm{m}$ Pt layer (Pt/Ti). The highest performance of the PEM electrolyzer

263 was achieved with this dual coating deposited on the anode and cathode side. Additional results

264 suggest that no coating is necessary on the cathode side, if stainless steel is to be use as base

265 material for manufacturing the BBPs. Furthermore, cheaper steels, $\mathrm{Cu}$, or $\mathrm{Al}$ can possibly be

266 used instead of stainless steel since corrosion was not observed. However, the BPP made of these

267 metals would require a coating on both sides to protect against any possible corrosion

268 phenomena, in particular during the stand-by periods. 
270 The authors are deeply grateful to the Federal Ministry for Economic Affairs and Energy

271 (BMWi), project No. 0325440A, and the internal funding program: Helmholtz association

272 (HGF), POF III for financial support. We also thank Anke Steinhilber for XPS analysis, Ina

273 Plock for the SEM images, and Svenja Kolb, Jörg Bürkle for their technical support in the

274 electrochemical measurements.

\section{References}

1. Royal Society of Chemistry, Chem. World, 2003, Enterp. electrolysis

(2003)

277 http://www.rsc.org/chemistryworld/Issues/2003/August/electrolysis.asp.

278 2. J. H. Russell, L. J. Nuttall, and A. P. Fickett, Am. Chem. Soc. Div. Fuel Chem. Prepr., 18, 24-33 (1973).

279 3. A. Sternberg et al., Energy Environ. Sci., 8, 389-400 (2015) http://xlink.rsc.org/?DOI=C4EE03051F.

280 4. K. E. Ayers, C. Capuano, and E. B. Anderson, ECS Trans., 41, 15-22

281 http://ecst.ecsdl.org/content/41/10/15.abstract.

282 5. K. E. Ayers, L. Moulthrop, E. B. Anderson, E. C. S. Transactions, and T. E. Society, ECS Trans., 41, 75-83 283 (2012) http://ecst.ecsdl.org/content/41/46/75.abstract.

284 6. M. Carmo, D. L. Fritz, J. Mergel, and D. Stolten, Int. J. Hydrogen Energy, 38, 4901-4934 (2013)

285 http://www.sciencedirect.com/science/article/pii/S0360319913002607.

286 7. F. Barbir, Sol. Energy, 78, 661-669 (2005).

287 8. L. Bertuccioli et al., Study on development of water electrolysis in the EU by E4tech Sàrl with Element Energy 288 Ltd for the Fuel Cells and Hydrogen Joint Undertaking, (2014).

289 9. K. E. Ayers et al., ECS Trans., 33, 3-15 (2010) http://ecst.ecsdl.org/content/33/1/3.abstract.

290 10. K. Zeng and D. Zhang, Prog. Energy Combust. Sci., 36, $307-326 \quad$ (2010) 291 http://www.sciencedirect.com/science/article/pii/S0360128509000598.

292 11. Fuel Cells and Hydrogen Joint Undertaking, Commercialisation of energy storage in europe, A fact-based 293 analysis of the implications of projected development of the European electric power system towards 2030 and 294 beyond for the role and commercial viability of energy storage, p. 52, (2015).

295 12. K. A. Friedrich, Studie über die Planung einer Demonstrationsanlage zur Wasserstoff - Kraftstoffgewinnung 296 durch Elektrolyse mit Zwischenspeicherung in Salzkavernen, p. in press, (2015).

297 13. S. A. Grigoriev, P. Millet, S. A. Volobuev, and V. N. Fateev, Int. J. Hydrogen Energy, 34, 4968-4973 (2009) 298 http://www.sciencedirect.com/science/article/pii/S0360319908015528.

299 14. $\quad$ H. Ito et al., Int. J. Hydrogen Energy, 37, 7418-7428

300 http://www.sciencedirect.com/science/article/pii/S0360319912001917.

301 15. M. A. Hoeh et al., Electrochem. commun., 55, 55-59 (2015) 302 http://www.sciencedirect.com/science/article/pii/S1388248115000776.

303 16. $\quad$ H. $\quad$ Ito et al., Int. J. Hydrogen Energy, 35, 9550-9560 (2010) 304 http://www.sciencedirect.com/science/article/pii/S036031991001284X. 
17. A. S. Tijani, D. Barr, and A. H. A. Rahim, Energy Procedia, 79, 195-203 (2015) http://www.sciencedirect.com/science/article/pii/S1876610215021943.

307 18. H. G. Kim, L. K. Kwa, W. Han, L. K. Kwac, and W. Han, in International Conference on Power and Energy 308 Systems Lecture Notes in Information Technology, Vol.13, vol. 13, p. 373-379 (2012) http://www.ier309 institute.org/2070-1918/lnit13/v13/373.pdf.

310 19. C. K. Jin, M. G. Jeong, and C. G. Kang, Int. J. Hydrogen Energy, 1-9 (2014) 311 http://dx.doi.org/10.1016/j.ijhydene.2014.03.013.

312 20. J.-T. T. Wang, W.-W. W. Wang, C. Wang, and Z.-Q. Q. Mao, Int. J. Hydrogen Energy, 37, 12069-12073 (2012) 313 http://www.sciencedirect.com/science/article/pii/S0360319912010798.

314 21. H.-Y. Jung, S.-Y. Huang, and B. N. Popov, J. Power Sources, 195, 1950-1956 (2010) 315 http://www.sciencedirect.com/science/article/pii/S0378775309017352.

316 22. S. S. Dihrab, K. Sopian, M. A. Alghoul, and M. Y. Sulaiman, Renew. Sustain. Energy Rev., 13, 1663-1668 317 (2009) http://www.sciencedirect.com/science/article/pii/S1364032108001676.

318 23. D. R. Hodgson, B. May, P. L. Adcock, and D. P. Davies, J. Power Sources, 96, 233-235 (2001).

24. R. A. Antunes, M. C. L. Oliveira, G. Ett, and V. Ett, Int. J. Hydrogen Energy, 35, 3632-3647 (2010) http://linkinghub.elsevier.com/retrieve/pii/S0360319910001308. http://dx.doi.org/10.1016/j.jpowsour.2012.01.104. http://www.sciencedirect.com/science/article/pii/S0360319914024549.

27. H. Husby, O. E. Kongstein, A. Oedegaard, and F. Seland, Int. J. Hydrogen Energy, 39, 951-957 (2014) http://www.sciencedirect.com/science/article/pii/S0360319913026281.

28. W. J. Pech-Rodríguez, D. González-Quijano, G. Vargas-Gutiérrez, and F. J. Rodríguez-Varela, Int. J. Hydrogen Energy, 39, 16740-16749 (2014) http://www.sciencedirect.com/science/article/pii/S0360319914009379.

29. Z. Wang et al., Int. J. Hydrogen Energy, 41, 5783-5792 http://www.sciencedirect.com/science/article/pii/S0360319915314944.

30. A. Kumar, M. Ricketts, and S. Hirano, J. Power http://linkinghub.elsevier.com/retrieve/pii/S037877530901564X.

Sources,

195, 1401-1407 http://linkinghub.elsevier.com/retrieve/pii/S0378775309002845.

32. H. Sun, K. Cooke, G. Eitzinger, P. Hamilton, and B. Pollet, Thin Solid Films, 528, 199-204 (2013) http://www.sciencedirect.com/science/article/pii/S0040609012013776. http://dx.doi.org/10.1016/j.jihydene.2011.09.060.

34. Y.-C. Park et al., Int. J. Hydrogen Energy, 38, 10567-10576 http://www.sciencedirect.com/science/article/pii/S0360319913014493. . http://www.sciencedirect.com/science/article/pii/S0257897206001034.

37. T. Valente and F. P. Galliano, Surf. Coatings http://www.sciencedirect.com/science/article/pii/S0257897200005491. http://www.sciencedirect.com/science/article/pii/025789729190214H.

349 39. A. S. Gago et al., J. Power Sources, 307, 815-825

350 http://www.sciencedirect.com/science/article/pii/S0378775315306832. 
40. A. S. Gago et al., ECS Trans., 64, 1039-1048 (2014) http://ecst.ecsdl.org/cgi/doi/10.1149/06403.1039ecst.

41. T. J. Toops et al., J. Power Sources, 272, 954-960 (2014) http://www.sciencedirect.com/science/article/pii/S0378775314014220.

42. H.-Y. Jung, S.-Y. Huang, P. Ganesan, and B. N. Popov, J. Power Sources, 194, 972-975 (2009) http://linkinghub.elsevier.com/retrieve/pii/S0378775309010441.

43. S. P. S. Badwal, S. Giddey, and F. T. Ciacchi, Ionics (Kiel)., 12, 7-14 (2006) http://link.springer.com/10.1007/s11581-006-0002-x.

44. S. A. Grigoriev, K. A. Dzhus, D. G. Bessarabov, and P. Millet, Int. J. Hydrogen Energy, 39, 20440-20446 (2014) http://www.sciencedirect.com/science/article/pii/S0360319914013913. 45. M. K. Debe et al., J. Electrochem. Soc., 159, K165-K176 (2012) http://jes.ecsdl.org/content/159/6/K165.full. 46. Ö. F. Selamet, F. Becerikli, M. D. Mat, and Y. Kaplan, Int. J. Hydrogen Energy, 36, 11480-11487 (2011). 47. W. Yoon, X. Huang, P. Fazzino, K. L. Reifsnider, and M. A. Akkaoui, J. Power Sources, 179, 265-273 (2008) http://www.sciencedirect.com/science/article/pii/S0378775307027024.

48. L. Wang et al., J. Power Sources, 195, 3814-3821 (2010).

49. H. Wang, M. A. Sweikart, and J. A. Turner, J. Power Sources, 115, 243-251 (2003).

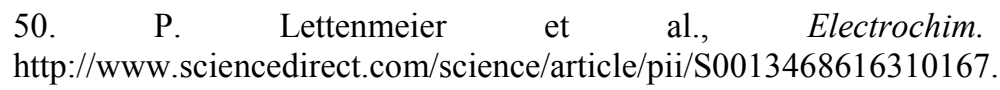

51. I. Dedigama et al., Int. J. Hydrogen http://www.sciencedirect.com/science/article/pii/S0360319914000755.

Energy, 39, 4468-4482 52. P. Lettenmeier, S. Kolb, F. Burggraf, A. S. Gago, and K. A. Friedrich, J. Power Sources, 311, 153-158 (2016) http://www.sciencedirect.com/science/article/pii/S0378775316301008.

53. F. Arbabi et al., J. Power Sour

373 http://www.sciencedirect.com/science/article/pii/S0378775314002262.

Sources, $\quad \mathbf{2 5 8}, \quad 142-149$

55. S. Sun, Z. Shao, H. Yu, G. Li, and B. Yi, J. Power Sources, 267, 515-520 (2014) http://linkinghub.elsevier.com/retrieve/pii/S0378775314008106.

56. P. Millet, F. Andolfato, and R. Durand, Int. J. Hydrogen Energy, 21, 87-93 (1996) http://www.sciencedirect.com/science/article/pii/0360319995000054. http://linkinghub.elsevier.com/retrieve/pii/S0360319910002648. http://linkinghub.elsevier.com/retrieve/pii/S0360319915018340. http://www.sciencedirect.com/science/article/pii/0025541672901097. http://www.sciencedirect.com/science/article/pii/0001616088900326. http://www.corrosionjournal.org/doi/abs/10.5006/0010-9312-21.2.53.

Corrosion, 21, 53-56

62. E. Herms, J. . Olive, and M. Puiggali, Mater. Sci. Eng. A, 272, 279-283 http://www.sciencedirect.com/science/article/pii/S0921509399003196. 


\section{Tables}

396 Table 1. Arrangement of coated stainless steel (ss) bipolar plates in the stack.

\begin{tabular}{lll}
\hline Cell & Anode bipolar plate & Cathode bipolar plate \\
\hline 1 & Baseline $^{\mathrm{a}}$ & Baseline $^{\mathrm{a}}$ \\
2 & Baseline $^{\mathrm{a}}$ & Baseline $^{\mathrm{a}}$ \\
3 & $\mathrm{Ti} / \mathrm{ss}$ & Baseline $^{\mathrm{a}}$ \\
4 & $\mathrm{Ti} / \mathrm{ss}$ & $\mathrm{Ti} / \mathrm{ss}$ \\
5 & $\mathrm{Pt} / \mathrm{Ti} / \mathrm{ss}$ & $\mathrm{Ti} / \mathrm{ss}$ \\
6 & $\mathrm{Pt} / \mathrm{Ti} / \mathrm{ss}$ & $\mathrm{Pt} / \mathrm{Ti} / \mathrm{ss}$ \\
\hline${ }^{\mathrm{a}}$ Coated titanium bipolar plate. The coating (non-disclosed) is proprietary technology of Hydrogenics
\end{tabular}

398 Table 2. XPS analysis of the DI water resin in the anode cycle of the PEM electrolyzer system

399 before (fresh) and after (used) $1000 \mathrm{~h}$ constant performance at $1 \mathrm{~A} \mathrm{~cm}^{-2}$.

\begin{tabular}{lll}
\hline Element & $\begin{array}{l}\text { Fresh } \\
{[w t \%]}\end{array}$ & $\begin{array}{l}\text { Used } \\
{[w t \%]}\end{array}$ \\
\hline $\mathrm{O}$ & 10.9 & 18.5 \\
$\mathrm{C}$ & 79.6 & 72.9 \\
$\mathrm{~S}$ & 7.2 & 6.2 \\
$\mathrm{Si}$ & 0 & 1.8 \\
$\mathrm{Fe}$ & 0 & 0.1 \\
$\mathrm{Ti}$ & 0 & 0.3 \\
$\mathrm{Ir}$ & 0 & 0.2 \\
$\mathrm{~N}$ & 2.4 & - \\
\hline
\end{tabular}

400 
403 Fig. 1. a) Stack (E92, Hydrogenics) $120 \mathrm{~cm}^{2}$ 6-cell stack tested in b) a $0.75-2.5 \mathrm{Nm}^{3} \mathrm{H}_{2} \mathrm{~h}^{-1}$

404 "Hylyzer" PEM electrolyzer unit (Hydrogenics). c) Cross-section SEM image of a Ti-coated 405 stainless steel bipolar plate before sanding; d) Cutaway of a corner between the channel of the 406 flow field and contact area with the current collector.

407 Fig. 2. a) Initial current-potential curves of cell $1-6$ from 0.01 to $1 \mathrm{~A} \mathrm{~cm}^{-2}$ and an scanning rate 408 of $4.2 \mathrm{~mA} \mathrm{~cm}^{-2} \mathrm{~s}^{-1}, 29^{\circ} \mathrm{C}$ and balanced pressure system of $6.5 \times 10^{5} \mathrm{~Pa}$; b) Nyquist plot of the 409 initial EIS measurement at $27^{\circ} \mathrm{C}, 0.166 \mathrm{~A} \mathrm{~cm}^{-2}$ and an amplitude current of $3 \mathrm{~A}$. The apex of the 410 frequency is indicated on top.

411 Fig. 3. Cell potential $\left(E_{\text {cell }}\right)$ during the $1000 \mathrm{~h}$ test on cell $1-6$ at $1 \mathrm{~A} \mathrm{~cm}^{-2}$, at $38{ }^{\circ} \mathrm{C}$ and balanced 412 pressure system of $6.5 \times 10^{5} \mathrm{~Pa}$.

413 Fig. 4. a) Current- potential curves of cell 1 to cell 6 from 0 to $1 \mathrm{~A} \mathrm{~cm}^{-2}$ and at $29{ }^{\circ} \mathrm{C}$ after $1000 \mathrm{~h}$ 414 test at constant $1 \mathrm{~A} \mathrm{~cm}^{-2}$; b) Nyquist plot of the EIS measurement at $27{ }^{\circ} \mathrm{C}, 0.166 \mathrm{~A} \mathrm{~cm}^{-2}$ and an 415 amplitude current of $3 \mathrm{~A}$ after $1000 \mathrm{~h}$ constant operation at $1 \mathrm{~A} \mathrm{~cm}^{-2}$. The apex of the frequency 416 is indicated on top.

417 Fig. 5. a) Cell potential of cell 1 to cell 6 at $1 \mathrm{~A} \mathrm{~cm}^{-2}, 29^{\circ} \mathrm{C}, 6.5 \times 10^{5} \mathrm{~Pa}$ and at three time steps, 418 initial, after $500 \mathrm{~h}$ and after $1000 \mathrm{~h}$ constant performance at $1 \mathrm{~A} \mathrm{~cm}^{-2}$. b) Initial ohmic resistance 419 (R1) of cell 1 to cell 6 and after $1000 \mathrm{~h}$ constant performance at $1 \mathrm{~A} \mathrm{~cm}^{-2}$ at $27^{\circ} \mathrm{C}$.

420 Fig. 6. Interface contact resistance (ICR) with respect of compaction pressure of plate 4 (Ti/ss) 421 and plate $6(\mathrm{Pt} / \mathrm{Ti} / \mathrm{ss})$ after $1000 \mathrm{~h}$ constant performance at $1 \mathrm{~A} \mathrm{~cm}^{-2}$ at $38{ }^{\circ} \mathrm{C}$. The anode and 422 cathode sides of the Ti/ss BPP were sanded to remove any oxide layer. 
423 Fig. 7. Post-mortem cross-section SEM images a) Ti and b) Pt/Ti coatings on stainless steel 424 BPPs after the $1000 \mathrm{~h}$ test at constant $1 \mathrm{~A} \mathrm{~cm}^{-2}$. 


\section{Fig. 1.}
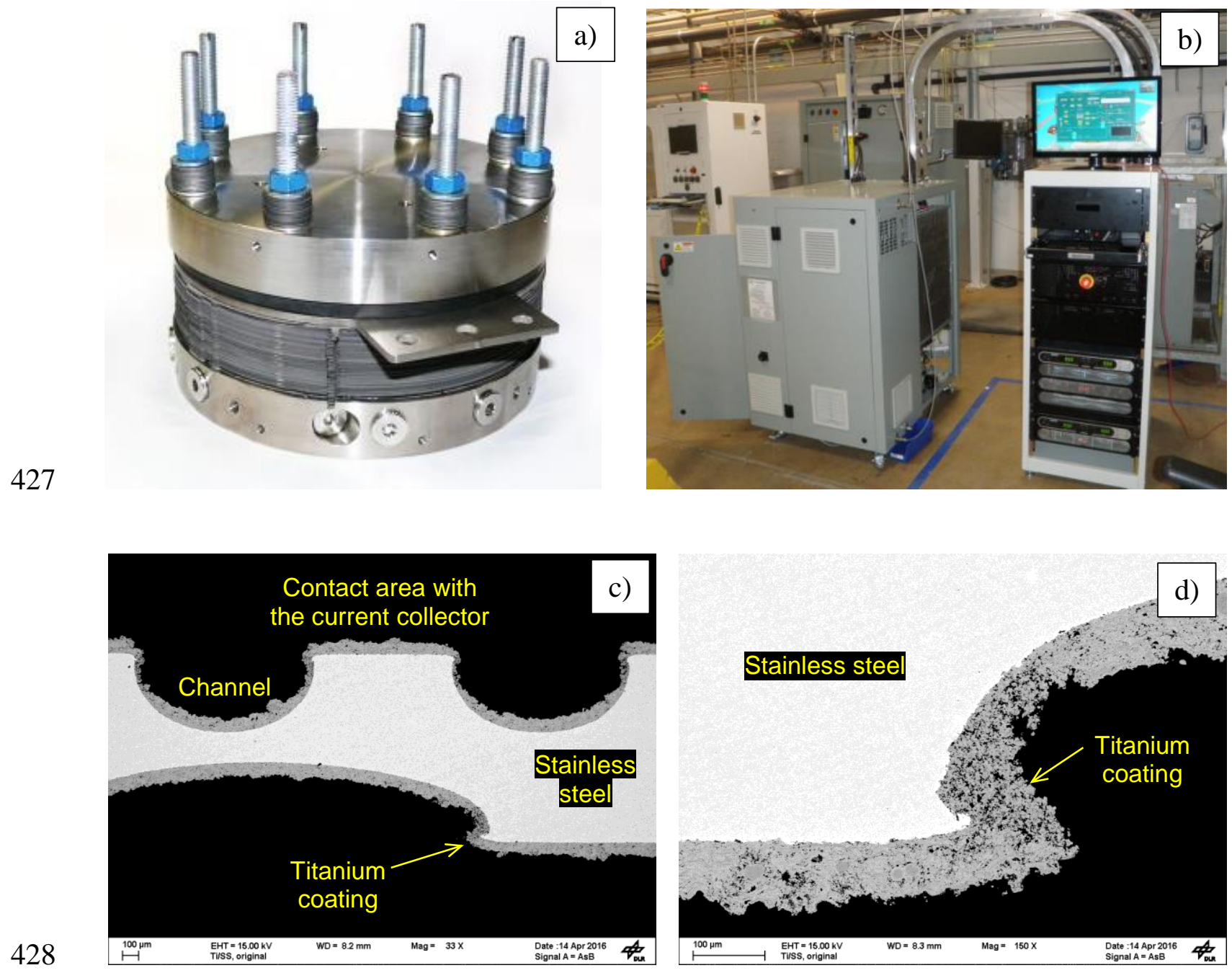
Fig. 2.

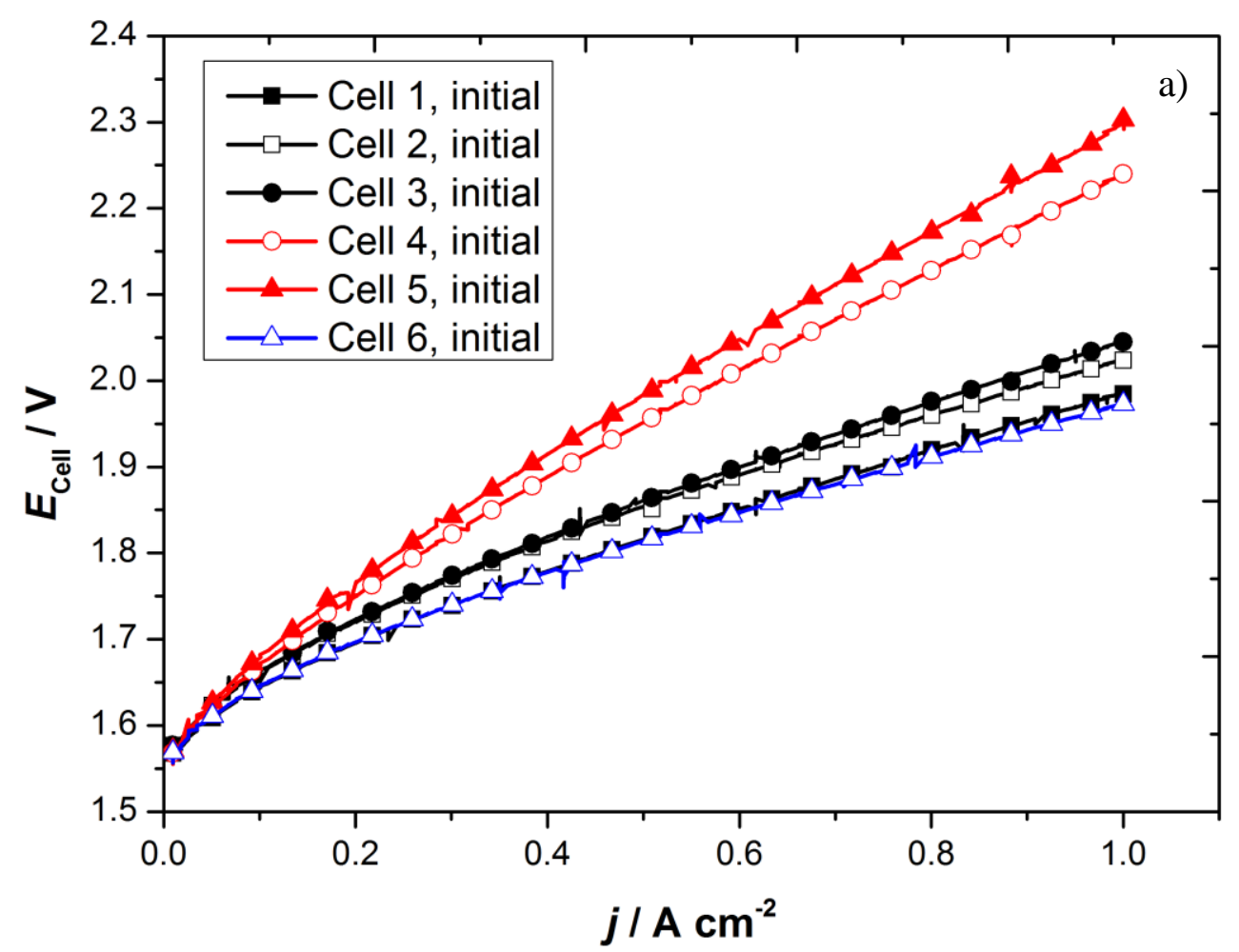

432

433

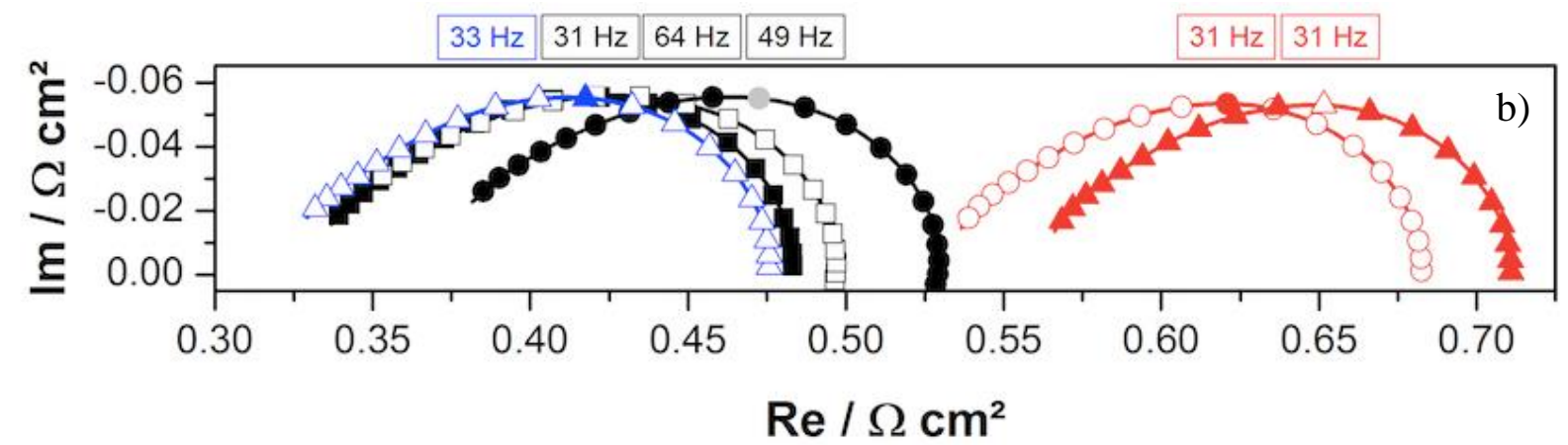

434

436 
$437 \quad$ Fig. 3.

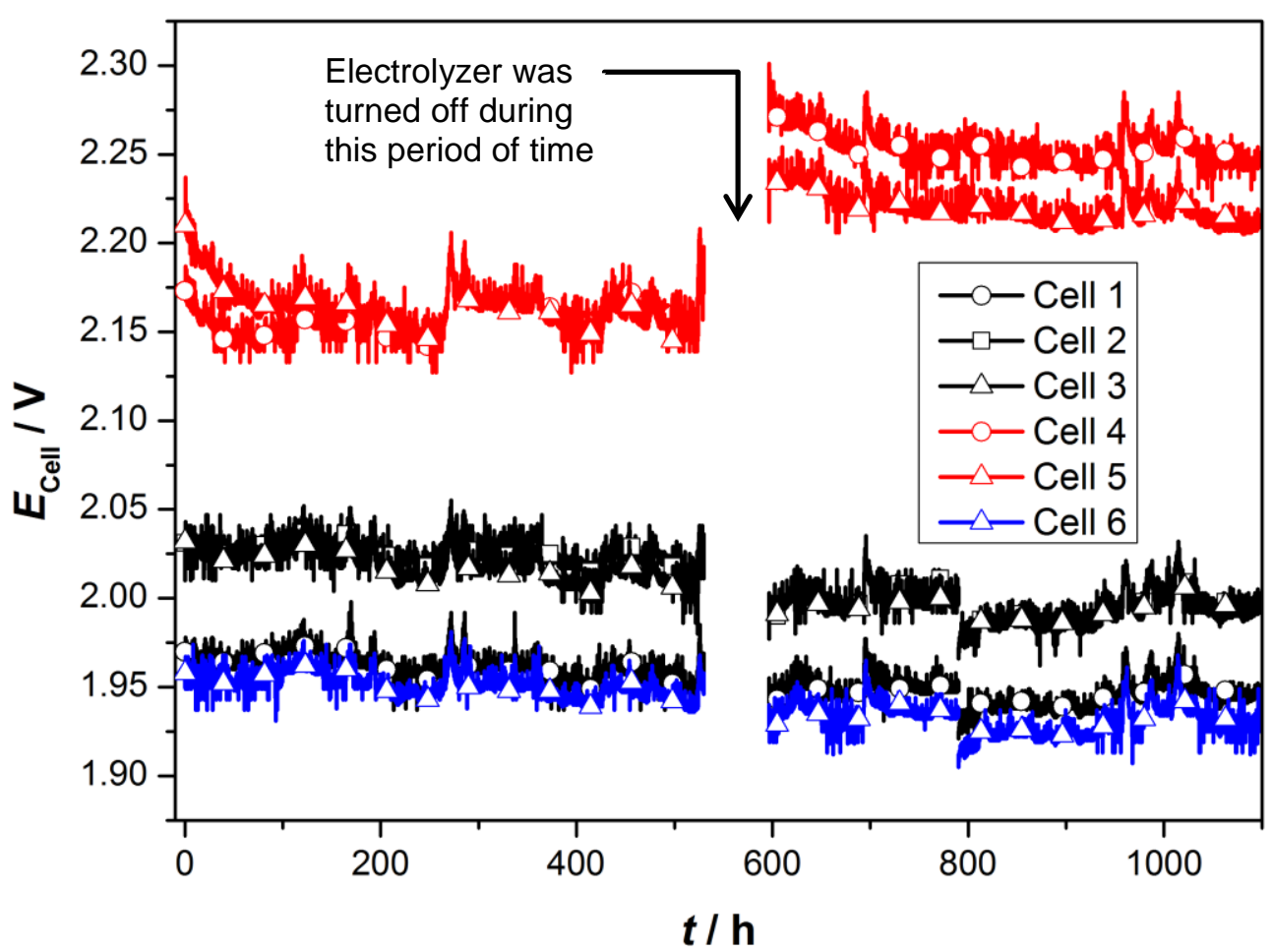

438 
Fig. 4.

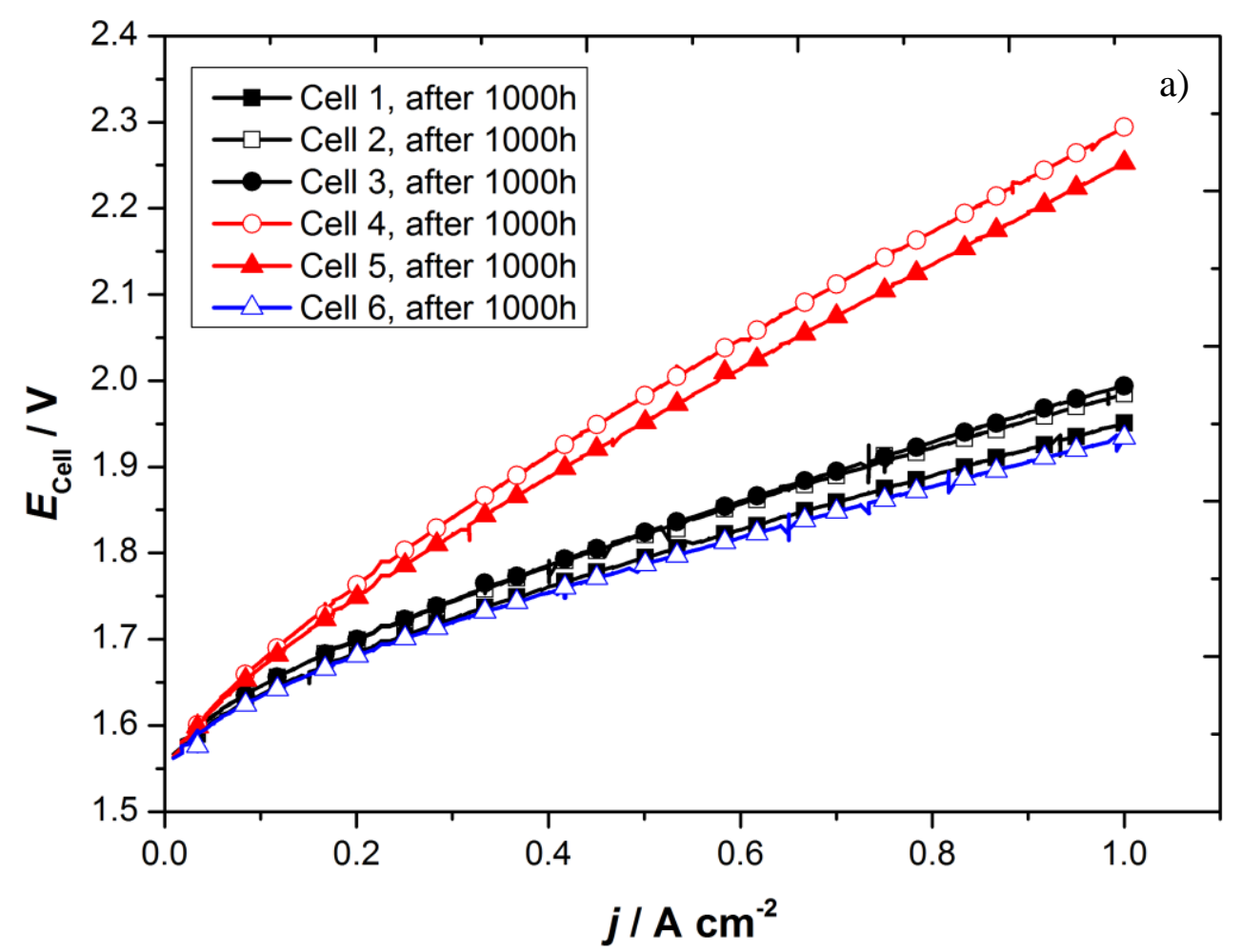

440

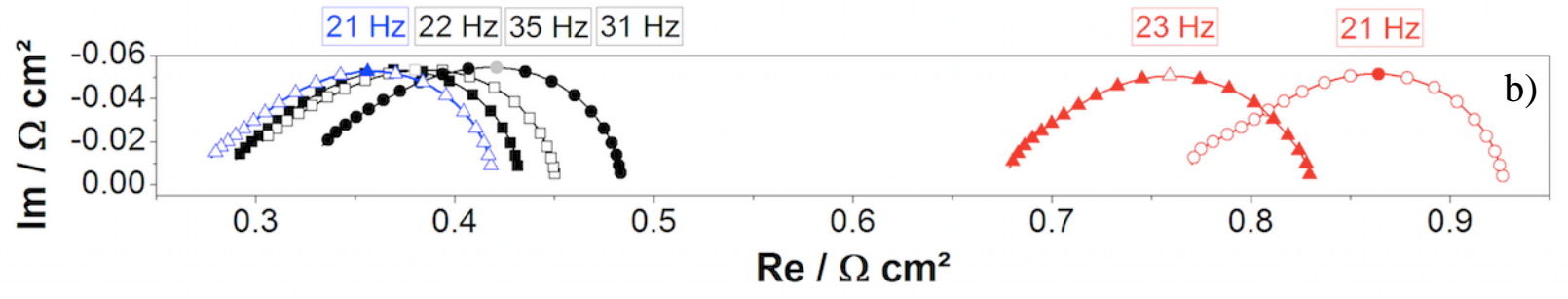

441

442 


\section{$443 \quad$ Fig. 5.}

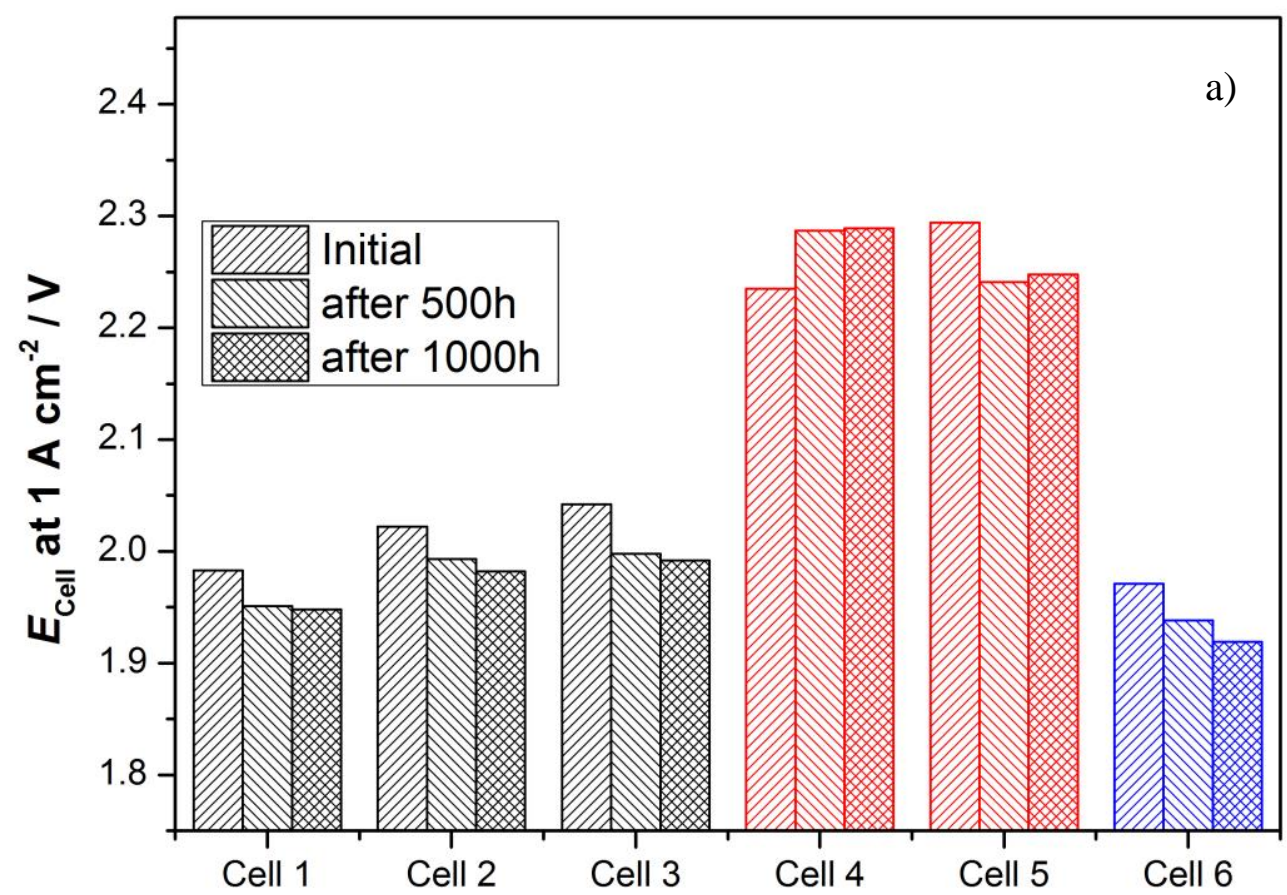

444

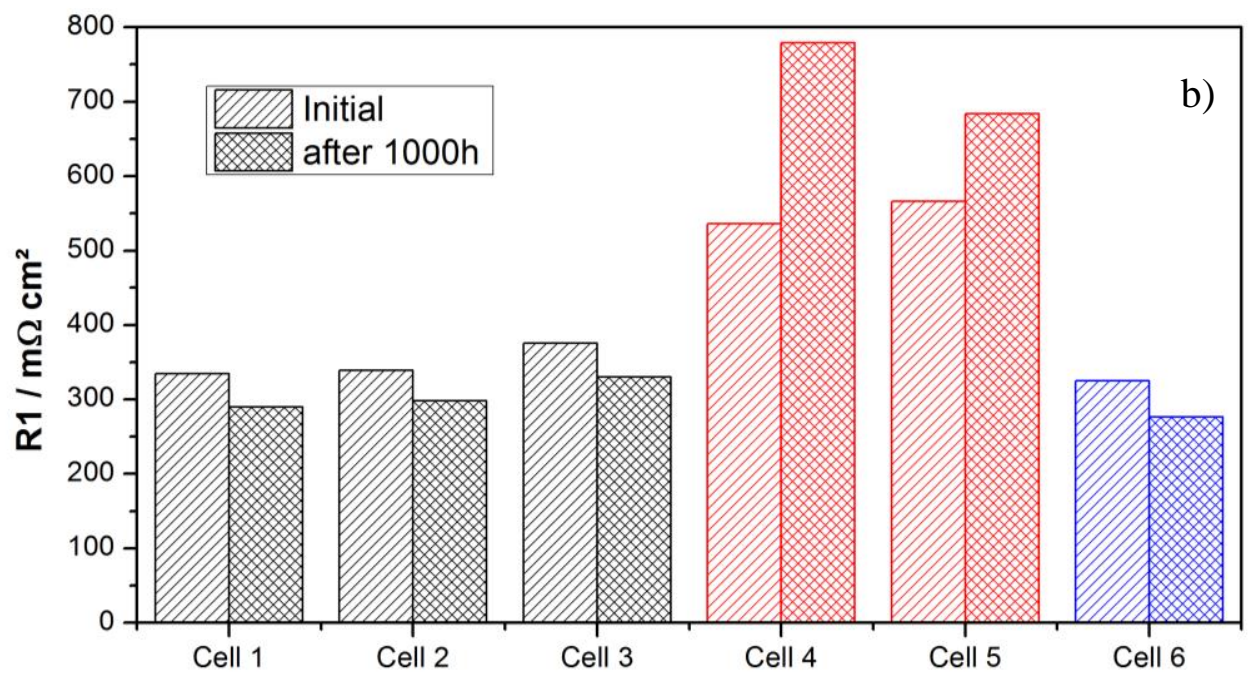


Fig. 6.

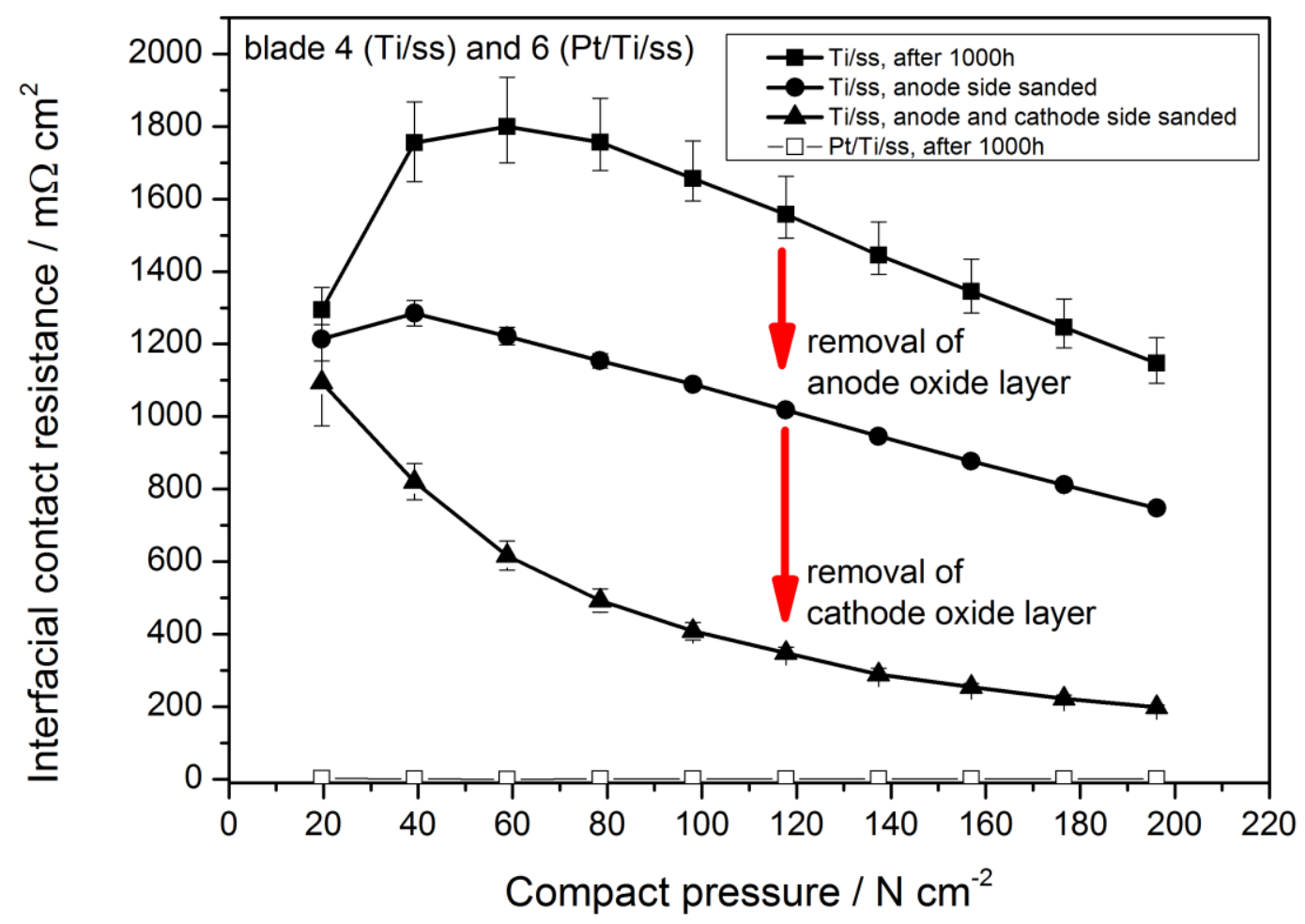


$449 \quad$ Fig. 7.
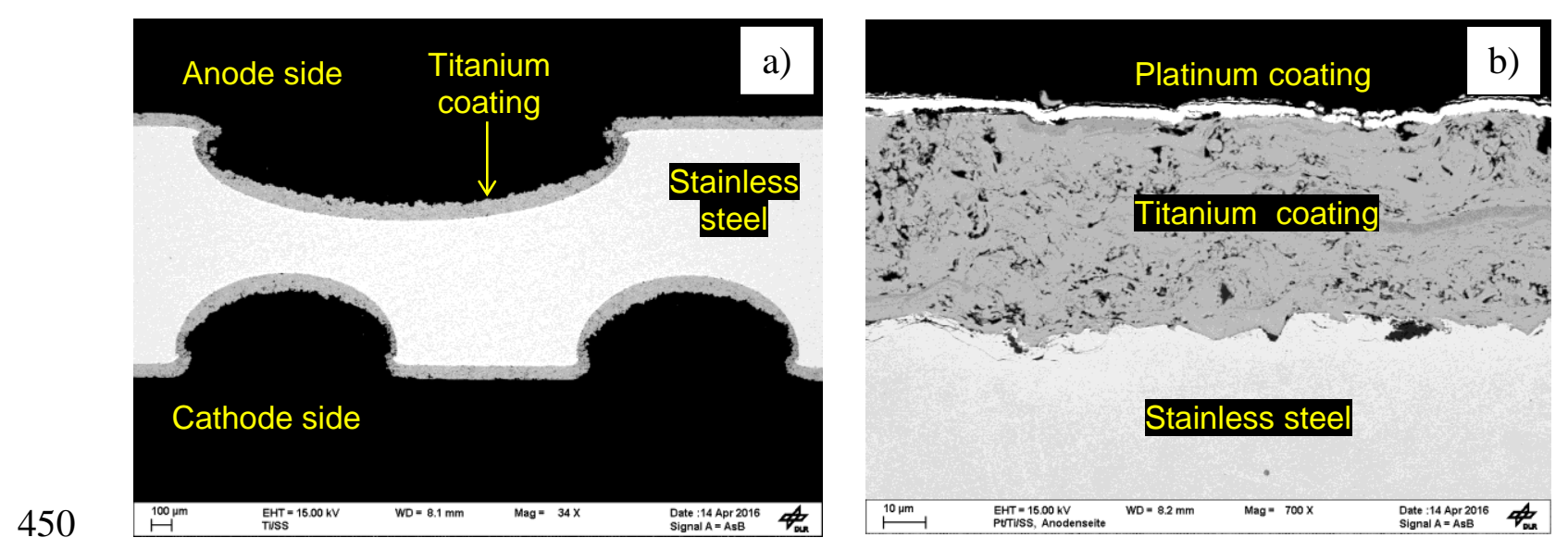

451

452 